ISBN 978-93-84422-76-9

International Conference on Research \& Innovation in Environment, Civil and Architecture Engineering

(RIECAE-17)

Bangkok (Thailand), Feb. 6-7, 2017

\title{
Basic Study on Term of Warranty Liability for Window and Door Work Defect in Apartment Building
}

\author{
Junmo Park ${ }^{1}$, and Deokseok Seo ${ }^{2 *}$ \\ ${ }^{1}$ Kyungsan Engineering Co., LTD., Korea. Email id: adviser.cm@gmail.com \\ $2^{2 *}$ Halla University, Korea. Email id: seodk@ halla.ac.kr
}

\begin{abstract}
In Korea, as lawsuits surrounding the defects of apartments, which are the main housing of the people, are rapidly, it is becoming a social problem. Although the term of warranty liability is the exclusion period of the claim for defect repair, there is no basis for establishing related systems. Since the consequences of defect lawsuits vary greatly according to the term of warranty liability, it has very important meaning for business subject and division owner. Therefore, the definition and period setting for the term of warranty liability should be reasonable. In this study, as a result of reviewing the history of laws and regulations related to the term of warranty liability, any document of grounds could not be found. In addition, it is confirmed the limitations of the institutional aspect that it has never been able to present objective grounds once in several revisions. On the other hand, in order to supplement for this, this study analyzed the trend of defects occurring every year for window and door work defects of apartments. We investigated defects of window and door work in 177 apartment complexes, total of 125,816 households, and as a result of analysis, window and door work showed many defects occurring in the first and second year, and extremely few after the third year. On the other hand, there was a slight difference by the detailed construction type, but there was less variation than the finish work subjected in the previous study.
\end{abstract}

Keywords: Window and door work defect; defect lawsuit; apartment building; enforcement decree of the housing ACT.

\section{Introduction}

As urbanization rapidly progressed in the 1980s and 1990s in Korea, apartment housing became a universal housing type. Especially, apartments which mean collective housing of five or more stories, are the main residential type. Korea's apartments account for more than half of all houses and 59\% as of 2010 [1].

As Korea's apartments have various social infrastructures that are not available in detached housing, convenience is excellent. Because of this, many Koreans live and are hoping to live in apartments [2].

Since the 2000s, Koreans' awareness of housing has changed drastically, recognizing housing as an important asset, not simply a housing space. As a result, the residents residing in apartments are maintaining a safe and pleasant apartment, while paying great attention to preserving asset value as real estate.

Because of this change in social atmosphere, various problems in apartments are becoming a social issue. Among them, defect disputes over the various problems such as cracks in concrete leakage of piping, etc. occurring in such apartments are increasing. Since the mid-2000s, lawsuits between business subject and division owner about the defects of apartment buildings in Korea have been soaring, which has become a big social problem.

However, compared with the rapidly changing economic and social structure, the relevant legal system and technical standards are not fully supported. The current law does not even have a clear definition of defects in apartments. In addition, the technical standards for apartments have only regulations concerning design and construction. Therefore, it is urgent to revise the social code about apartment defects. 
In particular, the term of warranty liability is very important debate. The term of warranty liability is interpreted as the right period for claiming defect repair or the period of obligations for defect repair. In other words, if the term of warranty liability is exceeded, the subject of business is not obligated to perform the defect repair, and the residents lose the right to claim defect repair [3]. Therefore, it is very important how to set the term, since the most of dispute begins within the term of warranty liability

However, there is no basis for establishing the term of warranty liability in the related laws, and it is a problem because the item and period are arbitrarily extended or deleted. In the early 1980s, when the law was first enacted, the foundation of the social system was relatively weak due to the mid-industrialization period [4]. However, even in the 2000s when the economy and society achieved stability, they have not been able to establish the foundation of the system. This point is representative of the underdevelopment of the entire construction-related system, and it can be reconfirmed that the system hinders the development of the construction industry and does not support the promotion of construction technology.

Therefore, in order to alleviate the extremely conflicting relationship between the business subject and the division owner, and to smoothly resolve the defect lawsuit for the apartment, it is necessary to develop an objective logical system and to improve the system based on scientific and quantitative analysis of the term of warranty liability.

\subsection{Purpose}

This study sought for a method to improve the fact that there are no grounds for establishing the term of warranty liability in the current laws such as the Housing Act and the Housing Management Act. We identified the actual defect status occurred in the apartment, and carried out a basic study to calculate the term of warranty liability based on this.

\subsection{Scope and Method}

The term of warranty liability stipulated in the Housing Act in Korea applies to both detached housing and collective housing. In Korea, collective housing is divided into apartment, tenement housing and multi-family housing depending on the number of floor and size of the houses. In this study, apartment among various types of collective housing was limited. This is because the main object of the defect dispute is the apartment, and it is easy to obtain the dispute data about the apartment relatively.

On the other hand, the term of warranty liability stipulated in the Housing Act is different for each of the 18 construction types related to housing construction. According to the nature of the construction work, the construction content is complicated for each facility construction, and the types of defect occurrence are different. Therefore, this study was conducted on window and door work.

\section{Literature Review}

\subsection{Definition of Window and Door Work Defect}

In the house law, window and door work of apartment is classified into window frame and door work, metallic material work for window and door, and glass work for window and door. Since the window and door work defects mainly cause inconvenience of the residents because there are many functional defects, they are becoming the major issue in disputes.

The types of defects that occur in window frame and door work, as typical examples, are 'poor opening and closing', 'non-building of end pieces on wooden door', and 'poor fire door'. The typical defects in the metallic material work for window and door are 'poor door check' and 'poor door lock' The most common defects in glass work for window and door are 'unlicensed changing and non-building glass' and 'poor glass for window and door' (Table 1). 
TABLE I: Defect Type on Window and Door Work

\begin{tabular}{|c|l|l|}
\hline Work & $\begin{array}{c}\text { Detailed Work } \\
\text { Type }\end{array}$ & $\begin{array}{c}\text { Typical Defect in Window and Door } \\
\text { Work }\end{array}$ \\
\hline \multirow{4}{*}{$\begin{array}{c}\text { Window } \\
\text { and } \\
\text { door } \\
\text { work }\end{array}$} & $\begin{array}{l}\text { Window Frame } \\
\text { and door work }\end{array}$ & $\begin{array}{l}\text { Poor opening and closing } \\
\text { Non-building of end pieces on } \\
\text { wooden door } \\
\text { Poor fire door }\end{array}$ \\
\cline { 2 - 3 } & $\begin{array}{l}\text { Metallic } \\
\text { for window and } \\
\text { door }\end{array}$ & $\begin{array}{l}\text { Poor door check } \\
\text { Poor door lock }\end{array}$ \\
\cline { 2 - 3 } & $\begin{array}{l}\text { Glass work for } \\
\text { window and } \\
\text { door }\end{array}$ & $\begin{array}{l}\text { Unlicensed changing and non- } \\
\text { building a glass } \\
\text { Poor glass for window and door }\end{array}$ \\
\hline
\end{tabular}

\subsection{Term of Warranty Liability}

The term of warranty liability of an apartment is a exclusion period in which the division owner of the apartment can exercise the right to request defect repair from the subject of business. The reason why the term of warranty liability is important in the case of the apartment defect lawsuit is that it is judgment criterion on whether defect lawsuit can be established or not. In other words, the division owner can recognize the defects occurring in his apartment and apply for defect repair within the term of warranty liability.

The provisions of the term of warranty liability for apartments in Korea was first introduced as the term of warranty liability was first specified as the Regulations on the Management of Apartment Buildings were revised in 1981.

\subsection{History of Law Revision}

A summary of the history of changes in the laws and regulations on the term of warranty liability is as follows.

For the first time in 1981, the term of warranty liability was established for the first five years or ten years as the Decree on the Management of Apartment Houses was enacted. The system of the term of warranty liability was established for the first time in Regulations on the Management of Apartment Buildings in 1982. Since then, the term of warranty liability has been transferred to the Decree on the Management of Apartment Houses in 1998.

In addition, in 2003, the Decree on the Management of Apartment Houses and the Regulations on the Management of Apartment Buildings were abolished, and the related regulations were transferred to the Enforcement Decree of Housing Act and Housing Law Enforcement Regulations. As Housing Act Enforcement Decree of the Housing Act was revised in 2007, a new construction type was added and the term of warranty liability increased by one to two years.

\subsection{Problem of Related Law}

In addition, the matters related to the window and door work are as follows (Table 2). According to the Decree on the Management of Apartment Houses in 1981, window and door work included window frame, door frame and door construction, and metallic material work for window. The term of warranty liability was set at one year.

In 1986, window frames, door frames, and door works were changed to window frames and door works in Decree on Management of Apartment Houses. Since then, this name has been maintained, which is considered to be a simple mistake in Korean notation, but it is necessary to revise the name in the future.

In 1998, the Decree on the Management of Apartment Houses was transferred to Decree on the Management of Apartment Houses. In 2003, it was again transferred to the Enforcement Decree of the Housing Act.

In 2007, when significant revision to the terms of warranty liability were made, the term of warranty liability of window frame and door work and metallic material work for window and door was increased from 1 year to 2 years. In addition, glass work for window and door was newly established.

As a result of reviewing the terms of the term of warranty liability for window and door work, the term of warranty liability for the construction of the window, it still fails to provide a ground for establishing the term of warranty liability for window and door work while revising laws and regulations. The ground for establishing 
the construction item or a quantitative review of one or two years of the term of warranty liability has not been followed.

TABLE II : Law Revision On Window And Door Work

\begin{tabular}{|c|c|c|c|}
\hline Year & Related Law & Work & $\begin{array}{l}\text { Term of } \\
\text { Warranty } \\
\text { Liability }\end{array}$ \\
\hline \multirow{2}{*}{1981} & \multirow{2}{*}{$\begin{array}{l}\text { Enforcement Decree on } \\
\text { the Management of } \\
\text { Apartment Houses }\end{array}$} & $\begin{array}{l}\text { Window frame, } \\
\text { door frame, and } \\
\text { door work }\end{array}$ & 1 \\
\hline & & $\begin{array}{l}\text { Metallic material } \\
\text { work for window } \\
\text { and door }\end{array}$ & 1 \\
\hline \multirow[b]{2}{*}{1986} & \multirow{2}{*}{$\begin{array}{l}\text { Enforcement Decree on } \\
\text { the Management of } \\
\text { Apartment Houses }\end{array}$} & $\begin{array}{l}\text { Window Frame } \\
\text { and door work }\end{array}$ & 1 \\
\hline & & $\begin{array}{l}\text { Metallic material } \\
\text { work for window } \\
\text { and door }\end{array}$ & 1 \\
\hline \multirow[b]{2}{*}{1998} & \multirow{2}{*}{$\begin{array}{c}\text { Decree on the } \\
\text { Management of } \\
\text { Apartment Houses }\end{array}$} & $\begin{array}{l}\text { Window Frame } \\
\text { and door work }\end{array}$ & 1 \\
\hline & & $\begin{array}{l}\text { Metallic material } \\
\text { work for window } \\
\text { and door }\end{array}$ & 1 \\
\hline \multirow[b]{2}{*}{2003} & \multirow{2}{*}{$\begin{array}{l}\text { Enforcement Decree of } \\
\text { the Housing Act }\end{array}$} & $\begin{array}{l}\text { Window Frame } \\
\text { and door work }\end{array}$ & 1 \\
\hline & & $\begin{array}{l}\text { Metallic material } \\
\text { work for window } \\
\text { and door }\end{array}$ & 1 \\
\hline \multirow{3}{*}{2007} & \multirow{3}{*}{$\begin{array}{l}\text { Enforcement Decree of } \\
\text { the Housing Act }\end{array}$} & $\begin{array}{l}\text { Window Frame } \\
\text { and door work }\end{array}$ & 2 \\
\hline & & $\begin{array}{l}\text { Metallic material } \\
\text { work for window } \\
\text { and door }\end{array}$ & 2 \\
\hline & & $\begin{array}{l}\text { Glass work for } \\
\text { window and door }\end{array}$ & 1 \\
\hline
\end{tabular}

\section{Review on Occurrence of Defect Case}

\subsection{Outline}

In this chapter, we intended to roughly identify the overall status of defects occurred in apartment buildings and the defects occurred in window and door work. The subject of survey is an apartment complex built between 2002 and 2011. The number of the complex is 177, and the total number of households is 125,816 households. The contents of survey were investigated by the construction type of defects in the public space and the private space of the apartment. On the other hand, window and door work, which is the subject of this study, can occur in both private space and public space. It will be noted, however, that this analysis did not separate them separately.

\subsection{Occurrence of Total Defect}

A total of 1,449,745 defects were found in the apartment, the subject of survey, where the defects occurred. If listed from the one with a large number of defect occurrence, finish work was the most common with $42.54 \%$, The second was $13.72 \%$ in supply and drainage and sanitation arrangement work, and the third was $12.66 \%$ in window and door work. Through this, it can be confirmed that the window and door work is an important defect in terms of the number of defects. There were other defects in wood work, miscellaneous work and electricity and electric power facility work in order. On the other hand, the defect in the other 12 construction types of work except the six construction types above was confirmed to be relatively insignificant (Fig. 1). 


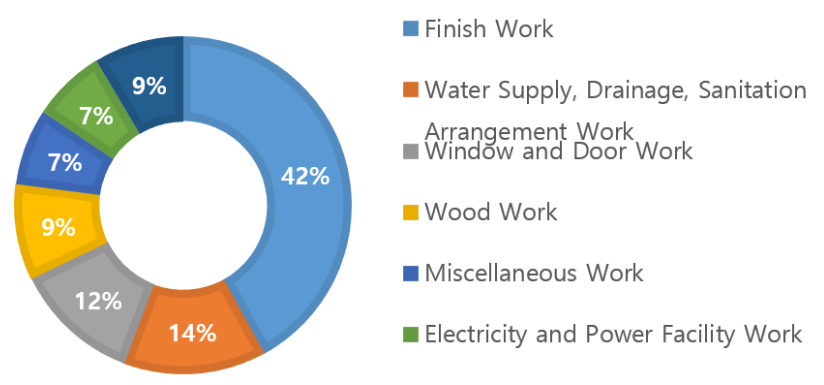

Fig. 1 Whole status of occurred defect

\subsection{Occurrence of Window and Door Work Defect}

The detailed status of defects caused by detailed construction type of window and door work is as follows (Fig. 3). Window frame and door work defects accounted for $79 \%$ of the total. Next, metallic material work for window and door was $13 \%$, glass work for window and door was $8 \%$.
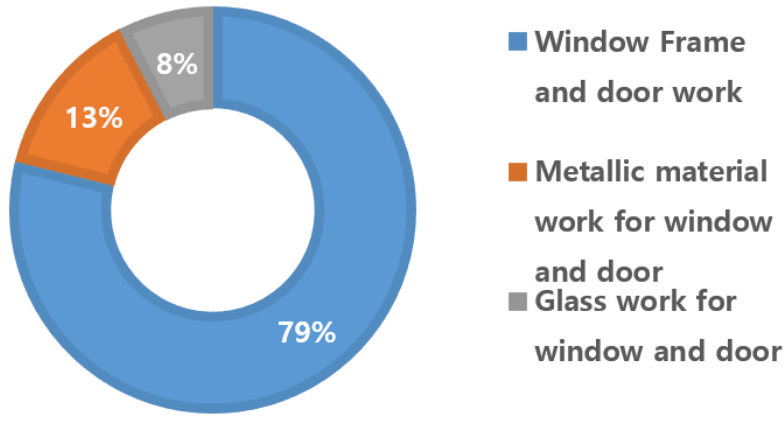

Fig. 2 Status of finish work defect

\section{Review on Occurrence Trend}

In this chapter, window and door work defects were examined by year, and the results were compared between the early part (1st 3rd year) and the latter part (5 10th year). In addition, the occurrence defect was accumulated every year and also examined the trend. It was reviewed when the year that the cumulative rate of occurrence defect reached $90 \%, 99 \%$ and $100 \%$, was respectively.

\subsection{Occurrence Trend of Window and Door Work Defect}

The number of defect occurrence per year and the number of defect occurrence accumulated annually for the total number of defects in the window and door work, are shown in the following graph (Figure 3). Looking at the defects in the former half, it was $67 \%$ in the first year of construction, $25 \%$ in the second year, and $6 \%$ in the third year. On the other hand, the defects that occurred after the fourth year were very few.

Looking at the cumulative number, the cumulative rate of defect occurrence was more than $90 \%$ in the second year and $99 \%$ in the fourth year. Through this, it can be confirmed that the defect occurrence of window and door work is centered at the former half. However, the defect occurrence cumulative rate of 100\% was in 10th year, which is insignificant, but it can be seen that defect occurrence continued even in the latter half. 


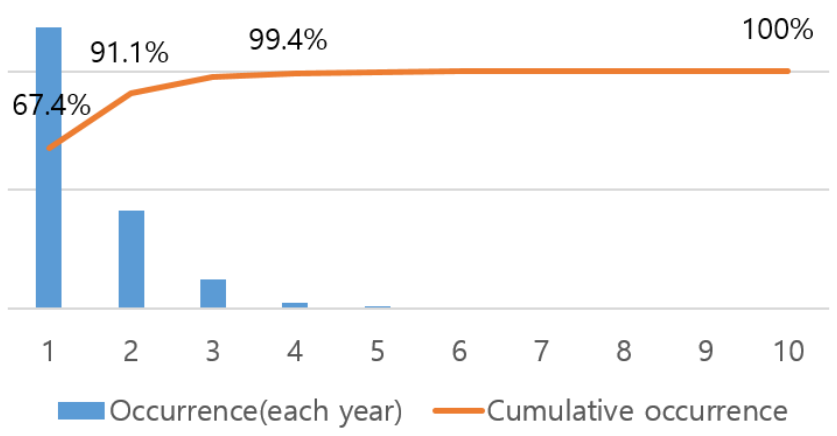

Fig. 3 Occurrence trend of total defect

\subsection{Window Frame and Door Work Defect}

The number of defect occurrence per year and the number of defect occurrence accumulated annually for the total number of defects in the window frame and door work are shown in the following graph (Figure 4). Looking at the defects in the former half, it was $65.8 \%$ in the first year of construction, $34 \%$ in the second year, and $7 \%$ in the third year. On the other hand, the defects that occurred after the fourth year were very few.

Looking at the cumulative number, the cumulative rate of defect occurrence was more than $90 \%$ in the second year and $99 \%$ in the fourth year. The tendency of defect occurrence in window frame and door work was similar to that of window and door work. On the other hand, the cumulative rate of defects was $100 \%$ in the 7 th year, which was faster than the total window and door work.

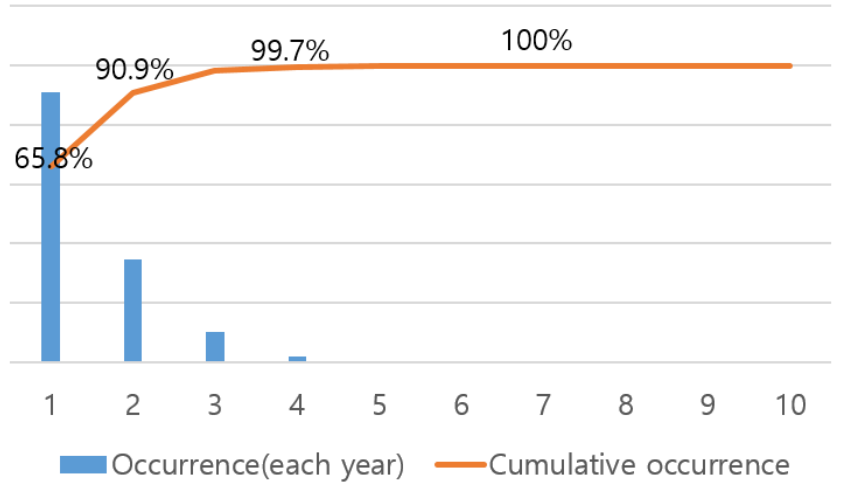

Fig. 4 Occurrence trend of window frame and door work defect

\subsection{Metallic Material Work Defect for Window and Door}

The number of defect occurrence per year and the number of defect occurrence accumulated annually for the total number of defects in the metallic material work for window and door are shown in the following graph (Figure 5). Looking at the defects in the former half, it was $70.6 \%$ in the first year of construction, $19 \%$ in the second year, and $5 \%$ in the third year. On the other hand, the defects that occurred after the fourth year were very few.

Looking at the cumulative number, the cumulative rate of defect occurrence was more than $90 \%$ in the fourth year and $99 \%$ in the fifth year. The cumulative rate of defect occurrence of $100 \%$ was confirmed in the tenth year. The tendency of defect occurrence in metallic material work for window and door was roughly similar to that of window and door work. 


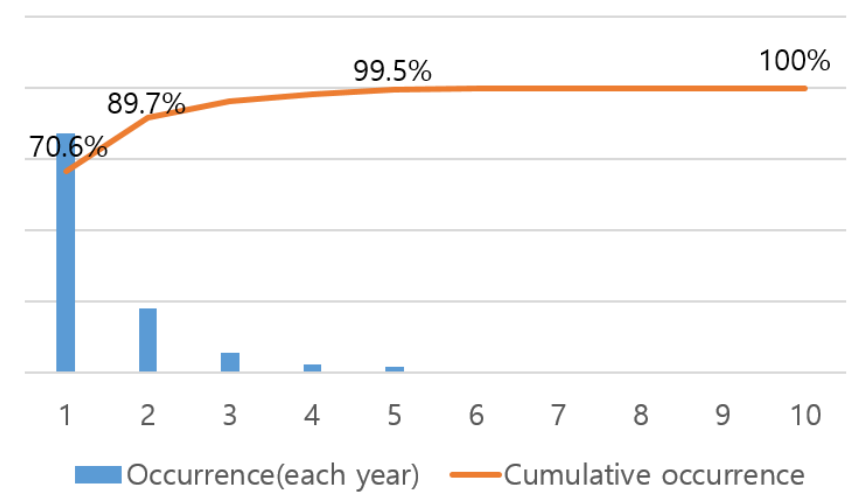

Fig. 5 Occurrence trend of metallic material work defect

\subsection{Glass Work Defect for Window and Door}

The number of defect occurrence per year and the number of defect occurrence accumulated annually for the total number of defects in the glass work for window and door are shown in the following graph (Figure 6). Looking at the defects in the former half, it was $78.5 \%$ in the first year of construction. $16.7 \%$ in the second year, and $3 \%$ in the third year. On the other hand, the defects that occurred after the fourth year were very few.

Looking at the cumulative number, the cumulative rate of defect occurrence was more than $90 \%$ in the second year and $99 \%$ in the third year. The tendency of defect occurrence in glass work for window and door was similar to that of window and door work. However, the defect occurrence cumulative rate of $100 \%$ was in the 6th year, which was faster than the overall window and door work.

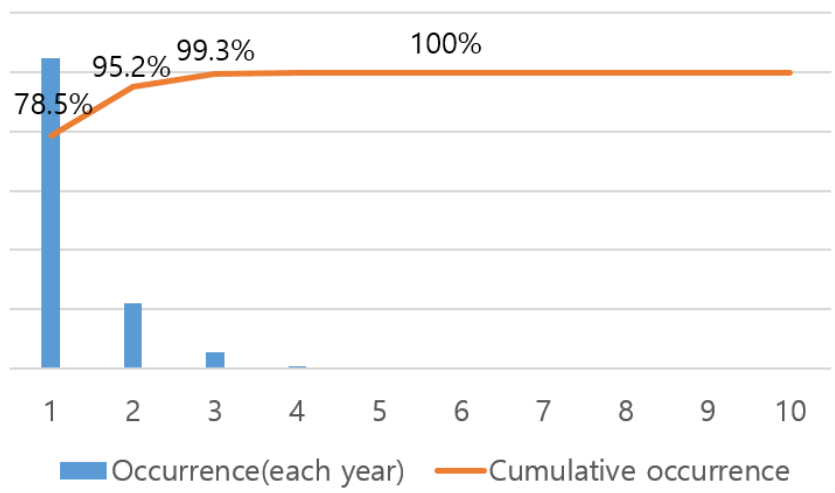

Fig. 6 Occurrence trend of glass work defect

\subsection{Result and Implication}

The results of analyzing the trends of defect occurrence by year and the trends of defect occurrence cumulative rate in window and door work of apartment are summarized as follows.

First, the trends of defect occurrence by year of the window frame and door work showed a similar tendency when compared to the overall window and door work. The case of metallic material work for window and door and glass work for window and door showed a similar tendency, but the defect occurrence in the first year were relatively more common.

Second, in terms of the trends of cumulative rate of defect occurrence, the total window and door work reached $90 \%$ in the second year and $99 \%$ in the fourth year. For each detailed construction type, window frame and door work showed the same tendency. On the other hand, there was a slight difference between metallic material work for window and door and glass work for window and door. Also, when the cumulative rate reached $100 \%$, window frame and door work was 7 years, glass work for window and door was 6 years, while metallic material work for window and door was 10 years.

In this chapter, the analysis of the tendency of defects occurred in window and door work implies the following points. 
First, window and door work tend to concentrate at $89.7 \sim 95.2 \%$ in the cumulative rate of occurrence defect in the first and second years. Similar results were obtained in the previous study [3], which analyzed the occurrence of defects in the finish work of the apartment.

However, in the case of window and door work, the proportion of the occurrence of the first year is higher than that of the finish work. In addition, in the case of finish work, the proportion of the occurrence of the first year by detailed construction type varies greatly, while window and door work is relatively small.

Second, examining the time when the cumulative rate of occurrence defect is $100 \%$, window frame and door work and glass work for window and door are in the middle part of 6th to 7th year. On the other hand, the cumulative rate of occurrence of the metallic material work for window and door was not until the 10th year when the term of warranty liability ended. This is because the metallic material work for window and door is relatively short in the cycle of defect occurrence.

\section{Conclusion}

In Korea, lawsuits over the defect of apartment building are constantly becoming a social problem. In lawsuits over the defect the apartment building, the term of warranty liability, as the period that can demand the defect repair according to defect occurrence, is important because it is the exclusion period of the exercise of rights.

However, over 40 years have elapsed without any grounds for establishing the term of warranty liability. In order to resolve disputes between the business subject and the division owner, the definition and period setting for the term of warranty liability should be reasonable.

For this purpose, this study reviewed the history of laws and regulations related to the term of warranty liability. As a result, any document of grounds for the term of warranty liability first established in 1981 could not be found. In addition, it is confirmed the limitations of the institutional aspect that it has never been able to present objective grounds once in several revisions.

On the other hand, in order to supplement for this, this study analyzed the trend of defects occurring every year for window and door work defects of apartments. as a result of analysis, window and door work showed many defects occurring in the first and second year, and extremely few after the third year. There was a slight difference by the detailed construction type, but there was less variation than the finish work subjected in the previous study.

In future, we will carry out in-depth analysis on whether the trend of defect occurrence in window and door work and the trend of defect occurrence by detailed construction type coincide with each other.

\section{Acknowledgment}

This work was supported by the National Research Foundation of Korea (NRF) grant funded by the Korea government (2016R1A2B4012485).

\section{References}

[1] J. Park ad D. Seo, "Basic Study on Standard Process Model for Defect Consulting in Korea," in Proc. International Workshops Materiial, Architecture and Civil Engineering 2014, Jeju, Korea, 2014, pp. 33-38

[2] J. Park and D. Seo, "Basic Study on Influence Factors for Defect Repairing Cost of Apartment Building in Korea," in Proc. 2016 International Conference on Applied Mathematics and Mechanics, Bangkok, Thailand, 2016, pp.

[3] J. Park and D. Seo, "Basic Study on Term of Warranty Liability for Finish Work Defect in Apartment Building," in Proc. 2017 International Conference on Studies in Architecture, Civil, Construction and Environmental Engineering, Bally, Indonesia, 2017, pp.

[4] J. Park and D. Seo, "Suggestion on Estimating Rate for Defect Repairing Deposit through Case Study of Defect Lawsuit in Korean Apartment Building," in Proc. International Conference on Nanotechnology, Environmental and Civil Engineering, Bangkok, Thailand, 2016, pp 


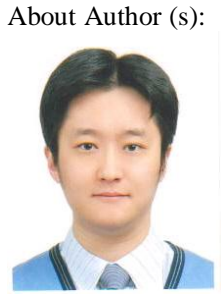

Junmo Park was born in 1980 in Seoul, South Korea. He currently lives in Seoul and works for Kyungsan Engineering. He majored in Architectural Engineering at the Chungbuk National University in Korea, graduated in 2006 with a master's degree in 2008, and received his Ph.D in 2012. Since 2005, he has been involved in various research and development projects commissioned by the Korean government and corporations and has lectured at many universities since 2010. Research on the defects of apartment buildings has been carried out with Professor Deokseok Seo, with support from Korean government over 5 projects since 2008. Currently, he is working with Professor Deokseok Seo on the term of warranty liability for apartment housing.

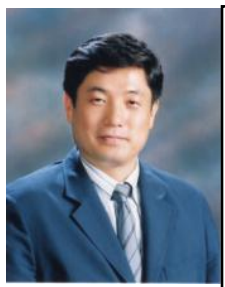

Deokseok Seo was born in Gongju, Korea in 1964. He currently lives in Wonju, Korea and is a professor of the College of Architecture at Halla University. He received bachelor's, master's, and doctoral degrees from Korea University in Korea. He also worked as a researcher at Korea Land \& Housing Corporation, the only professional public company in Korea's apartment houses. He is the first researcher who received a doctorate in research on defects in apartment housing in Korea. Until now, he has been conducting various researches with government support on defects in apartment houses. In 2016, he was also listed in the World Dictionary of Marquis Who's Who in the World. In addition, he received a commendation from the Minister of Education as an excellent researcher. He has done various researches with Dr. Junmo Park, and has written academic papers and thesis. Recently, with the support of the Korea Research Foundation, a specialized research institute under the Ministry of Education, Korea, he is conducting a study on the term of warranty liability in apartment buildings. 